\title{
Analisis Pengaruh Stres Kerja Dan Disiplin Kerja Terhadap Kepuasan Kerja \\ (Studi Pada Pegawai PT Angkasa Pura II (Persero) Kantor Cabang Bandara Husein Sastranegara Bandung)
}

\author{
Ricardo Manarintar Simarmata \\ Politeknik Negeri Ambon. Ambon, Maluku, Indonesia \\ Email: ricardomanarintar@gmail.com
}

(Diterima: Juli 2021; Direvisi: Juli 2021; Dipublikasikan: September 2021)

\begin{abstract}
ABSTRAK
Penelitian ini bertujuan untuk melihat Analisis Pengaruh Stres Kerja Dan Disiplin Kerja Terhadap Kepuasan Kerja Pegawai (Studi pada pegawai PT Angkasa Pura II (Persero) Kantor Cabang Bandara Husein Sastranegara Bandung. Populasi dalam penelitian ini adalah pegawai PT Angkasa Pura II (Persero) Kantor Cabang Bandara Husein Sastranegara Bandung, yaitu 192 orang. Teknik pengambilan sampel yang digunakan dalam penelitian ini menggunakan teknik probability sampling. Penelitian ini akan menguji analisis pengaruh stress kerja dan disiplin kerja terhadap kepuasan kerja (studi pada pegawai PT Angkasa Pura II (Persero) Kantor Cabang Bandara Husein Sastranegara Bandung). Dalam penelitian kali ini, teknik analisis yang akan digunakan adalah multiple regression. Peneliti menemukan bahwa sebagian besar item sudah cukup valid dalam mengukur variabel yang ingin diukur. Namun, peneliti menemukan pada variabel disiplin kerja, item nomor 13 dan 21 dinyatakan tidak valid dan pada variabel kepuasan kerja item nomor 32 dan 33 dinyatakan tidak valid. Ketiga variabel yang diteliti (stres kerja, disiplin kerja dan kepuasan kerja) dapat dianggap sudah reliabel. Karena memiliki nilai reliabilitas Alpa Cronbach lebih dari 0.6. Dari hasil penelitian, para responden memiliki stres kerja yang berada di taraf tinggi, disiplin kerja yang berada di taraf rendah, dan kepuasan kerja yang berada di taraf rendah. Terdapat pengaruh yang signifikan secara simultan stres kerja dan disiplin kerja terhadap kepuasan kerja para responden pegawai PT Angkasa Pura II (Persero) Kantor Cabang Bandara Husein Sastranegara Bandung.
\end{abstract}

\section{Kata Kunci: Stress Kerja, Disiplin Kerja, Kepuasan kerja}




\section{PENDAHULUAN}

Era globalisasi yang ditandai dengan semakin maju dan berkembang kegiatan pembangunan baik di bidang ekonomi, sosial, budaya maupun keamanan membawa dampak terhadap meningkatnya berbagai permasalahan sosial di dalam berbagai aspek kehidupan masyarakat, sehingga menuntut kepekaan berbagai unsur untuk merespon permasalahan dan kesiapan untuk menghadapi situasi dan kondisi yang terjadi.

Demikian pula halnya dengan PT Angkasa Pura II (Persero) Kantor Cabang Bandara Husein Sastranegara Bandung sebagai suatu organisasi, harus kritis dengan semakin kompleks nya permasalahan yang terjadi saat ini. Selain itu, tuntutan atas kualitas pelayanan yang diberikan oleh pegawai pada masyarakat masih memerlukan perhatian, misalnya kecepatan dalam memberikan pelayanan, dan kemudahan prosedur pelayanan.

Salah satu faktor penting yang sangat menentukan dalam melakukan pemecahan masalah adalah sumber daya manusia. Sumber daya manusia menurut Schumacher yang terkenal dengan bukunya Small is beautiful yang dikutip oleh Simamora (2004:18), mengatakan bahwa modal utama pembangunan yaitu sumber daya manusia, bukan sumber daya material atau uang, yang terakhir bersifat sekunder, sedangkan sumber daya manusia bersifat primer.

Mangkunegara

(2005:120) menyatakan bahwa kepuasan kerja pegawai akan meningkatkan kinerja pegawai. Berdasarkan pendapat diatas, kinerja pegawai PT Angkasa Pura II (Persero) Kantor Cabang Bandara Husein Sastranegara Bandung rendah disinyalir oleh ketidakpuasan pegawai itu sendiri. Menurut Luthans (2006:243), faktorfaktor yang menimbulkan kepuasan kerja adalah pekerjaan itu sendiri, promosi, pengawasan/supervisi, dan rekan kerja. Empat faktor tersebut sangat mempengaruhi sekali tingkat kepuasan kerja pegawai, hal-hal ini dapat dilihat dari indikator-indikator tersebut ;

Tabel 1. Hasil survey awal di Bandara Husein Sastranegara, Bandung

\begin{tabular}{|l|l|l|l|}
\hline No & $\begin{array}{l}\text { Indikator } \\
\text { Kepuasan Kerja }\end{array}$ & $\begin{array}{l}\text { Target Kepuasan } \\
\text { Kerja } \\
(\%)\end{array}$ & $\begin{array}{l}\text { Realisasi } \\
\text { Kepuasan } \\
(\%)\end{array}$ \\
\hline 1 & Pekerjaan & 80 & 73 \\
\hline 2 & Promosi & 82 & 75 \\
\hline 3 & Pengawasan & 85 & 77 \\
\hline 4 & Rekan Kerja & 84 & 72 \\
\hline
\end{tabular}

Tabel di atas, memperlihatkan bahwa setiap indikator kepuasan kerja pegawai memiliki target yang tidak mampu dicapai, hal ini memperlihatkan kepuasan kerja pegawai yang rendah, sebagaimana yang dikemukakan oleh Cherrington (2003:306) menyatakan "job satisfaction refers basically to how much employees like their jobs". Kondisi kerja yang kurang mendukung atau kurang menyenangkan akan menyebabkan ketidakpuasan kerja pada pegawai dalam bekerja dalam hal ini dapat dikatakan stres kerja yang tinggi serta 
disiplin kerja yang rendah akan menyebabkan ketidakpuasan pegawai dalam bekerja. Selain itu berdsasarkan survey awal (2016) yang dilakukan pada 5 orang pegawai, ternyata dihasilkan sebagai berikut : (1) gaji yang diterima masih terasa kurang, sehingga membuat pegawai mencari pekerjaan tambahan, (2) pengawasan dari atasan yang masih kurang ketat, dimana pegawai pada saat jam kerja masih bisa bolos dari tempat kerja, (3) mitra kerja yang kurang mendukung , sehingga membuat ketidakpuasan dalam bekerja.

$$
\text { Jehangir }
$$

menyimpulkan stres kerja mempunyai hubungan yang negatif dan signifikan dengan kepuasan kerja. Karena stres menjadi masalah utama dalam bekerja yang sangat berhubungan dengna kepuasan kerja. Berdasarkan pernyataan di atas, ternyata disinyalir ketidakpuasan pegawai PT Angkasa Pura II (Persero) Kantor Cabang Bandara Husein Sastranegara Bandung disebabkan oleh stres kerja yang tinggi.

Menurut Berg dan Theron (2006:291) berpendapat bahwa stres adalah kondisi yang terjadi ketika tuntutan yang dibuat pada orangorang melebihi kemampuan mereka. Berdasarkan penyataan di atas, diduga bahwa di samping ketidakpuasan pegawai yang menyebabkan rendahnya kinerja pegawai, juga stres kerja yang tinggi yang menyebabkan kinerja pegawai rendah.

Dari hasil pengamatan dan observasi penulis yang berkaitan dengan stres kerja di PT Angkasa Pura II (Persero) Kantor Cabang
Bandara Husein Sastranegara Bandung, diperoleh data-data sebagai berikut :

1. Banyak pegawai yang tidak masuk kerja tanpa informasi seperti sakit, sehingga membuat pekerjaan menumpuk dan pekerjaan dikerjakan oleh rekan kerja.

2. Pegawai mengeluh mengalami kelelehan secara fisik dalam bekerja.

3. Pegawai merasa pekerjaan yang diberikan kepada mereka terlalu banyak sehingga membuat produktifitas pegawai menurun.

Dari hasil pengamatan penulis dengan kondisi yang berkaitan dengan tingkat disiplin kerja di di PT Angkasa Pura II (Persero) Kantor Cabang Bandara Husein Sastranegara Bandung, dapat diuraikan sebagai berikut :

1. Banyak pegawai yang terlambat masuk kerja dan menggunakan alasan yang sama untuk membenarkan perilaku pegawai dan hal itu selalu menjadi rutinitas dalam bekerja.

2. Masih ada pegawai yang kurang patuh dalam peraturan sebagai contoh misalnya masih ada pegawai yang kurang memperhatikan tata cara berpakaian seperti misalnya masih ada pegawai yang memakai sendal, dan pemakaian baju seragam yang tidak sesuai.

Dari beberapa fenomena yang diuraikan di atas, dapat ditarik kesimpulan bahwa stres kerja di PT Angkasa Pura II (Persero) Kantor Cabang Bandara Husein Sastranegara Bandung masih tinggi demikian juga dengan tingkat disiplin kerja pegawai juga belum mencapai optimal seperti yang diharapkan perusahaan, 
sehingga dampaknya terlihat nyata pada level kinerja pegawainya yang belum menunjukkan nilai yang memuaskan bagi organisasi.

Berdasarkan uraian di atas, apabila dilihat dari tingkat kemampuan dan keterampilan pegawai di lingkungan PT Angkasa Pura II (Persero) Kantor Cabang Bandara Husein Sastranegara Bandung dianggap cukup memadai dengan rata-rata pengalaman dan masa kerja yang cukup lama namun tingkat pencapaian kinerja masih kurang optimal, maka kinerja yang kurang optimal diduga disebabkan oleh stres kerja yang tinggi dan disiplin kerja yang rendah yang akan berdampak pada ketidakpuasan kerja pegawai. Oleh karena itu penulis terdorong untuk melakukan kegiatan penelitian dengan judul "ANALISIS PENGARUH STRES KERJA DAN DISIPLIN KERJA TERHADAP KEPUASAN KERJA PEGAWAI (Studi pada Pegawai PT Angkasa Pura II (Persero) Kantor Cabang Bandara Husein Sastranegara Bandung)".

\section{TINJAUAN PUSTAKA}

\section{Stres Kerja}

Menurut

Luthans

(2006:243), Stres kerja adalah keadaan emosi yang senang atau emosi positif yang berasal dari penilaian pekerjaan atau pengalaman kerja seseorang. Menurut Robbins (2003:577), stres merupakan kondisi dinamis yang ada di dalamnya seorang individu dikonfrontasikan dengan suatu peluang, kendala (constraints), atau tuntutan (demands) yang dikaitkan dengan apa yang sangat diinginkan nya dan yang hasilnya dipersepsikan sebagai tidak pasti dan penting.

Mangkunegara (2008:179) mengemukakan stres kerja sebagai suatu ketegangan atau tekanan yang dialami ketika tuntutan yang dihadapkan melebihi kekuatan yang ada pada diri kita. Menurut Daft (2010:396), Stres kerja adalah kesulitan, ketidaknyamanan, melelahkan dan bahkan menakutkan. Stres menurut Kreitner dan Kinicki (2001:587) didefinisikan sebagai tanggapan perilaku, fisik, atau psikologis dari penyebab stres. Stres merupakan tanggapan adaptif, yang dimediasi oleh karakter individu dan/atau proses psikologikal, juga merupakan konsekuensi dari tindakan eksternal, situasi, atau kejadian yang menempatkan tuntutan khusus secara fisik dan/atau psikologi seseorang.

McShane dan Von Glinow (2003:199) juga mendifinisikan stres sebagai tanggapan adaptif individu terhadap suatu situasi yang dipersepsikan sebagai tantangan atau mengancam individu tersebut.

Handoko

(2008:167)

mengemukakan stres sebagai suatu kondisi ketegangan yang dapat mempengaruhi emosi, proses berfikir dan kondisi seseorang.

Dari beberapa definisi stres kerja di atas, dapat disimpulkan bahwa stres kerja adalah tanggapan adaptif perilaku, fisik, atau psikologis dari suatu situasi yang dipersepsikan sebagai tantangan atau mengancam individu tersebut dalam menghadapi pekerjaan, dapat berupa emosi tidak stabil, perasaan 
tidak tenang, suka menyendiri, sulit tidur, dan sebagainya.

\section{Disiplin Kerja}

Pengertian disiplin menurut Kamus Besar Bahasa Indonesia adalah ketaatan (kepatuhan) kepada peraturan (tata tertib dan sebagainya). Kata disiplin berasal dari bahasa latin "disciplina" yang berarti latihan atau pendidikan kesopanan dan kerohanian serta pengembangan tabiat.

Menurut T. Hani Handoko (2001:308) menjelaskan kedisiplinan adalah kegiatan manajemen untuk menjalankan standar-standar organisasi. Menurut Abdurrahman Fathoni (2006:172) menjelaskan kedisiplinan adalah kesadaran dan kesediaan seseorag menaati semua peraturan perusahaan dan norma sosial yang berlaku.

Menurut Atmodiwirio (2000:235), disiplin adalah suatu sikap, perbuatan untuk selalu mentaati tata tertib. Disiplin adalah sikap mental yang tercermin dalam perbuatan, tingkah laku perorangan, kelompok atau masyrakat berupa kepatuhan atau ketaatan terhadap peraturan peraturan, dan ketentuan yang ditetapkan pemerintah atau etik, norma, dan kaidah yang berlaku dalam masyarakat untuk tujuan tertentu. Menurut Meija, Balkin dan Cardy (Taufiqurrakhman, 2006:62), disiplin kerja adalah sarana yang digunakan oleh manajer untuk mengkomunikasikan kepada pegawai bahwa harus mengubah perilakunya.

Menurut E. Mulyasa (2002:118), disiplin merupakan sesuatu yang penting untuk menanamkan rasa hormat terhadap kewenangan, menanamkan kerja sama dan merupakan kebutuhan untuk berorganisasi, serta untuk menanamkan rasa hormat terhadap orang lain.

Menurut Keith Davis (2003:129), disiplin kerja dapat diartikan sebagai pelaksanaan manajemen untuk memperteguh pedoman pedoman organisasi. Menurut Wayne Mondy (2008:162), disiplin adalah kondisi kendali diri pegawai dan perilaku tertib yang menunjukkan tingkat kerja sama tim yang sesungguhnya dalam suatu organisasi.

Sedangkan menurut As. Munandar (Bahrodin, 2007:23), disiplin adalah bentuk ketaatan terhadap aturan telah ditetapkan. Menurut Robbims (2006:231), disiplin kerja dapat diartikan sebagai suatu sikap dan perilaku yang dilakukan secara sukarela dengan penuh kesadaran dan kesediaan mengikuti peraturan peraturan yang telah ditetapkan secara bersama baik secara tertulis maupun tidak tertulis.

\section{Kepuasan Kerja}

Menurut Robbin dan Judge (2008:301), Kepuasan kerja adalah sikap umum seseorang individu terhadap pekerjaan nya. seseorang dengan tingkat kepuasan kerja yang tinggi akan menunjukkan sikap yang positif terhadap pekerjaan nya sedangkan seseorang yang tidak puas dengan pekerjaan nya akan menunjukkan sikap yang negatif terhadap pekerjaan. Menurut Luthans (2006:243), kepuasan kerja adalah hasil dari persepsi pegawai 
mengenai seberapa baik pekerjaan mereka memberikan hal yang dinilai penting.

Menurut Moorhead dan Griffin (2013:71), kepuasan kerja adalah tingkat dimana orang menemukan kepuasan atau pemenuhan dalam pekerjaan mereka. Menurut Rivai dan Sagala (2013:856), job satisfaction merupakan evaluasi menggambarkan seseorang atas perasaan sikap senang atau tidak senang atau tidak puas dalam bekerja. Menurut Findik et al, 2013, yang menguatkan pendapat Mullins (2005:700), job satisfaction adalah suatu konsep yang kompleks dan berubah dari orang ke orang lainnya.

Menurut Nathania, dkk (2013:20), yang mengacu kepada konsep Spector (1985:695), job satisfaction adalah perasaan senang yang dirasakan oleh pegawai terhadap berbagai aspek dari pekerjaan nya. Menurut Wibowo (2014:3), yang mengacu kepada konsep Davis (2002:208), kepuasan kerja adalah seperangkat perasaan pegawai tentang menyenangkan atau tidak menyenangkan pekerjaan mereka. Masih menurut Wibowo (2014:3), yang mengacu pada konsep Handoko (2000), kepuasan kerja adalah keadaan emosional yang menyenangkan atau tidak menyenangkan dengan mana pegawai memandang pekerjaan mereka. Koesmono (2006:93), menyatakan kepuasan kerja adalah sebagai perasaan dan reaksi individu terhadap lingkungan pekerjaan nya.

\section{Hipotesis Penelitian}

Hipotesis yang peneliti ajukan adalah sebagai berikut:

H1 : Stres kerja berpengaruh terhadap kepuasan kerja.

$\mathrm{H} 2$ : Disiplin kerja berpengaruh terhadap kepuasan kerja

H3 : Stres kerja dan Disiplin kerja berpengaruh secarasimultan terhadap kepuasan kerja

\section{METODE PENELITIAN}

\section{Populasi}

Populasi dalam penelitian ini adalah karyawan PT Angkasa Pura II (Persero) Kantor Cabang Bandara Husein Sastranegara Bandung, yaitu 192 orang.

\section{Sampel}

Teknik pengambilan sampling dalam penelitian ini adalah probability sampling, dimana setiap anggota populasi mempunyai peluang yang sama untuk dijadikan sampel. Dengan demikian sampel dalam penelitian ini berjumlah 66 responden.

\section{Metode Analisis Data}

Metode yang dalam penelitian ini sesuai dengan tujuan yang diharapkan yaitu metode deskriptif dan verifikatif. Penelitian deskriptif adalah

penelitian yang bertujuan untuk memperoleh deskripsi tentang ciri-ciri variabel persepsi mengenai stress kerja, disiplin kerja, dan kepuasan kerja. Dalam menganalisis data digunakan uji validitas dan reliabilitas, uji asumsi klasik, uji normalitas, uji multikolinearitas, uji heteroskedastisitas, uji regresi berganda, dan uji hipotesis. 
HASIL PENELITIAN

1. Uji Regresi Linear Berganda

Uji Hipotesis Pengaruh

antara stres kerja dan disiplin kerja terhadap

kepuasan kerja

Peneliti melakukan

pengujian hipotesis dengan menggunakan regresi linear berganda. Sebelum melakukan analisis regresi linear berganda, dengan taraf kepercayaan sebesar $95 \%$, peneliti menetapkan hipotesis sebagai berikut :
- H0 : tidak terdapat pengaruh yang signifikan antara stres kerja terhadap kepuasan kerja pada para responden karyawan PT Angkasa Pura II Kantor Cabang Bandara Husein Sastranegara.

- H1 : Terdapat pengaruh yang signifikan antara stres kerja terhadap kepuasan kerja pada para responden karyawan PT Angkasa Pura II Kantor Cabang Bandara Husein Sastranegara.

Tabel 2.Tabel Uji Hipotesis

ANOVA $^{\mathrm{a}}$

\begin{tabular}{|c|c|c|c|c|c|c|}
\hline \multicolumn{2}{|c|}{ Model } & Sum of Squares & Df & Mean Square & $\mathrm{F}$ & Sig. \\
\hline \multirow{3}{*}{1} & Regression & 6.142 & 2 & 3.071 & 7.497 & $.001^{\mathrm{b}}$ \\
\hline & Residual & 25.808 & 63 & .410 & & \\
\hline & Total & 31.950 & 65 & & & \\
\hline
\end{tabular}

a. Dependent Variable: Kepuasan Kerja

b. Predictors: (Constant), Disiplin Kerja, Stress Kerja

Berdasarkan tabel diatas, peneliti menemukan nilai signifikansi sebesar $.001<\alpha=.050$, yang berarti Terdapat pengaruh yang signifikan antara stres kerja dan disiplin kerja

Tabel 3. Koefisien Kontribusi

Model Summary ${ }^{\mathrm{b}}$

\begin{tabular}{|c|c|r|r|r|}
\hline $\begin{array}{c}\text { Mo } \\
\text { del }\end{array}$ & $\mathrm{R}$ & $\begin{array}{c}\mathrm{R} \\
\text { Square }\end{array}$ & $\begin{array}{c}\text { Adjusted R } \\
\text { Square }\end{array}$ & $\begin{array}{r}\text { Std. Error of } \\
\text { the Estimate }\end{array}$ \\
\hline 1 & $.438^{\mathrm{a}}$ & .192 & .167 & .64003 \\
\hline
\end{tabular}

a. Predictors: (Constant), Disiplin Kerja, Stress Kerja

b. Dependent Variable: Kepuasan Kerja

Berdasarkan tabel di atas, peneliti menemukan bahwa pengaruh stres kerja terhadap kepuasan kerja sebesar .167, yang menggambarkan koefisien determinasi dari pengukuran. Dengan demikian, sebesar $16.7 \%$ dari kepuasan kerja terhadap kepuasan kerja pada para responden karyawan PT Angkasa Pura II Kantor Cabang Bandara Husein Sastranegara.

Tabel 4. Koefisien

Coefficients $^{\mathbf{a}}$

\begin{tabular}{|l|r|r|r|l|l|}
\hline \multirow{2}{*}{ Model } & \multicolumn{2}{|c|}{ Unstandardized Coefficients } & Standardized Coefficients & T & Sig. \\
\cline { 2 - 4 } & B & Std. Error & Beta & & \\
\hline 1 (Constant) & .564 & .846 & & -.667 & .507
\end{tabular}




\begin{tabular}{|l|r|r|r|r|r|}
\hline Stress Kerja & -.719 & .258 & .391 & 2.791 & .007 \\
Disiplin Kerja & .139 & .264 & .074 & .525 & .601 \\
\hline
\end{tabular}

a. Dependent Variable: Kepuasan Kerja

Berdasarkan tabel di atas, peneliti dapat membuat persamaan regresi sebagai berikut :

$$
y=a+b_{1} x_{1}+b_{2} x_{2}
$$

Kepuasan kerja $=564-719 \mathrm{x}$ stress kerja +139 x disiplin kerja

Dengan demikian, maka stres kerja memiliki pengaruh yang negatif, dimana peningkatan yang terjadi akan mengurangi kepuasan kerja yang dimiliki oleh responden. Sementara, peningkatan disiplin kerja akan meningkatkan kepuasan kerja yang dimiliki oleh responden.

\section{Uji Hipotesis Parsial Pengaruh antara stres kerja terhadap kepuasan kerja}

Peneliti melakukan pengujian hipotesis dengan menggunakan regresi linear berganda. Sebelum melakukan analisis regresi linear berganda, dengan taraf kepercayaan sebesar $95 \%$, peneliti menetapkan hipotesis sebagai berikut :

- H0 : tidak terdapat pengaruh yang signifikan antara stres kerja terhadap kepuasan kerja pada para responden karyawan PT Angkasa Pura II Kantor Cabang Bandara Husein Sastranegara.

- H1 : Terdapat pengaruh yang signifikan antara stres kerja terhadap kepuasan kerja pada para responden karyawan PT Angkasa Pura II Kantor Cabang Bandara Husein Sastranegara.

Tabel 5. Pengujian Statistik Pengaruh Stres Kerja Terhadap Kepuasan Kerja

\begin{tabular}{|c|c|c|c|c|c|}
\hline \multicolumn{6}{|c|}{ ANOVA $^{a}$} \\
\hline Model & Sum of Squares & Df & Mean Square & $\mathrm{F}$ & Sig. \\
\hline Regression & 6.029 & 1 & 6.029 & 14.887 & $.000^{\mathrm{b}}$ \\
\hline 1 Residual & 25.921 & 64 & .405 & & \\
\hline Total & 31.950 & 65 & & & \\
\hline
\end{tabular}

a. Dependent Variable: Kepuasan Kerja

b. Predictors: (Constant), Stress Kerja

Berdasarkan tabel diatas, peneliti menemukan nilai signifikansi sebesar $.000<\alpha=.050$, yang berarti Terdapat pengaruh yang signifikan antara stres kerja terhadap kepuasan kerja pada para responden karyawan PT Angkasa Pura II Kantor Cabang Bandara Husein Sastranegara

Tabel 6. Pengujian Statistik Pengaruh Stres Kerja Terhadap Kepuasan Kerja ANOVA $^{\mathrm{a}}$

\begin{tabular}{|c|c|c|c|c|c|}
\hline Model & Sum of Squares & Df & Mean Square & $\mathrm{F}$ & Sig. \\
\hline Regression & 6.029 & 1 & 6.029 & 14.887 & $.000^{\mathrm{b}}$ \\
\hline 1 Residual & 25.921 & 64 & .405 & & \\
\hline Total & 31.950 & 65 & & & \\
\hline
\end{tabular}

a. Dependent Variable: Kepuasan Kerja

b. Predictors: (Constant), Stress Kerja 
Berdasarkan tabel diatas, peneliti menemukan nilai signifikansi sebesar $.000<\alpha=.050$, yang berarti Terdapat pengaruh yang signifikan Tabel 7. Koefisien Kontribusi

Model Summary ${ }^{\mathbf{b}}$

\begin{tabular}{|r|r|r|r|c|}
\hline Model & \multicolumn{1}{|c|}{$\mathrm{R}$} & $\mathrm{R}$ Square & \multicolumn{1}{c|}{$\begin{array}{c}\text { Adjusted R } \\
\text { Square }\end{array}$} & $\begin{array}{c}\text { Std. Error of the } \\
\text { Estimate }\end{array}$ \\
\hline & $.434^{\mathrm{a}}$ & .189 & .176 & .63640 \\
\hline
\end{tabular}

a. Predictors: (Constant), Stress Kerja

Dependent Variable: Kepuasan Kerja

antara stres kerja terhadap kepuasan kerja pada para responden karyawan PT Angkasa Pura II Kantor Cabang Bandara Husein Sastranegara.

Berdasarkan tabel di atas, peneliti menemukan bahwa pengaruh stres kerja terhadap kepuasan kerja sebesar .176, yang menggambarkan koefisien determinasi dari pengukuran. Dengan demikian, sebesar $17.6 \%$ dari kepuasan kerja dipengaruhi oleh stres kerja yang dimiliki oleh responden. Sementara $82.4 \%$ dipengaruhi oleh variabel variabel lain yang tidak diukur dalam penelitian.

Tabel 8. Persamaan Regresi

Coefficients $^{\mathrm{a}}$

\begin{tabular}{|c|c|c|c|c|c|}
\hline \multirow[t]{2}{*}{ aModel } & \multicolumn{2}{|c|}{ Unstandardized Coefficients } & \multirow{2}{*}{$\begin{array}{c}\text { Standardized Coefficients } \\
\text { Beta }\end{array}$} & \multirow[t]{2}{*}{$\mathrm{t}$} & \multirow[t]{2}{*}{ Sig. } \\
\hline & B & Std. Error & & & \\
\hline (Constant) & .566 & .841 & & -.673 & .503 \\
\hline Stress Kerja & -.799 & 207 & .434 & 3.858 & .000 \\
\hline
\end{tabular}

a. Dependent Variable: Kepuasan Kerja

Berdasarkan tabel di atas, peneliti dapat membuat persamaan regresi sebagai berikut :

$$
\begin{gathered}
y=a+b_{1} x_{1}+b_{2} x_{2} \\
\text { kepuasan kerja } \\
=.566-.799 \times \text { stres kerja }
\end{gathered}
$$

Dengan demikian, maka stres kerja memiliki pengaruh yang negatif, dimana peningkatan yang terjadi akan mengurangi kepuasan kerja yang dimiliki oleh responden.

\section{Uji Hipotesis Pengaruh Parsial} antara disiplin kerja terhadap kepuasan kerja

Peneliti melakukan pengujian hipotesis dengan menggunakan regresi linear berganda. Sebelum

Tabel 9. Pengujian Hipotesis Pengaruh Disiplin Kerja Terhadap Kepuasan Kerja

ANOVA $^{\mathrm{a}}$

\begin{tabular}{|l|r|r|r|c|c|}
\hline Model & Sum of Squares & df & Mean Square & F & Sig. \\
\hline 1 Regression & 2.951 & 1 & 2.951 & 6.514 & $.013^{\mathrm{b}}$ \\
\hline
\end{tabular}

melakukan analisis regresi linear berganda, dengan taraf kepercayaan sebesar $95 \%$, peneliti menetapkan hipotesis sebagai berikut :

- H0 : tidak terdapat pengaruh yang signifikan antara disiplin kerja terhadap kepuasan kerja pada para responden karyawan PT Angkasa Pura II Kantor Cabang Bandara Husein Sastranegara.

- H1 : Terdapat pengaruh yang signifikan antara stres kerjadan disiplin kerja terhadap kepuasan kerja pada para responden karyawan PT Angkasa Pura II Kantor Cabang Bandara Husein Sastranegara. 


\begin{tabular}{|c|c|c|c|}
\hline Residual & 28.999 & 64 & .453 \\
\hline Total & 31.950 & 65 & \\
\hline
\end{tabular}

a. Dependent Variable: Kepuasan Kerja

b. Predictors: (Constant), Disiplin Kerja

Berdasarkan tabel diatas, peneliti menemukan nilai signifikansi sebesar $.013<\alpha=.050$, yang berarti Terdapat pengaruh yang signifikan antara disiplin kerja terhadap

kepuasan kerja pada para responden karyawan PT Angkasa Pura II Kantor Cabang Bandara Husein Sastranegara.

Tabel 10. Koefisien Kontribusi Pengaruh Disiplin Kerja Terhadap Kepuasan Kerja

Model Summary ${ }^{b}$

\begin{tabular}{|l|r|r|r|c|}
\hline Model & \multicolumn{1}{|c|}{$\mathrm{R}$} & $\mathrm{R}$ Square & \multicolumn{1}{|c|}{$\begin{array}{c}\text { Adjusted R } \\
\text { Square }\end{array}$} & $\begin{array}{c}\text { Std. Error of the } \\
\text { Estimate }\end{array}$ \\
\hline 1 & $.304^{\mathrm{a}}$ & .092 & .078 & .67313 \\
\hline
\end{tabular}

a. Predictors: (Constant), Disiplin Kerja

b. Dependent Variable: Kepuasan Kerja

Berdasarkan tabel di atas, peneliti menemukan bahwa pengaruh stres kerja terhadap kepuasan kerja sebesar .078, yang menggambarkan koefisien determinasi dari pengukuran. Dengan demikian, sebesar $7.8 \%$ dari kepuasan kerja dipengaruhi oleh disiplin kerja yang dimiliki oleh responden. Sementara 92.2\% dipengaruhi oleh variabel - variabel lain yang tidak diukur dalam penelitian.

Tabel 11. Persamaan Regresi

Coefficients $^{\mathbf{a}}$

\begin{tabular}{|c|c|c|c|c|c|c|}
\hline \multirow[t]{2}{*}{ Model } & \multicolumn{2}{|c|}{ Unstandardized Coefficients } & \multirow{2}{*}{\multicolumn{2}{|c|}{$\frac{\text { Standardized Coefficients }}{\text { Beta }}$}} & \multirow[t]{2}{*}{$\mathrm{t}$} & \multirow[t]{2}{*}{ Sig. } \\
\hline & B & Std. Error & & & & \\
\hline \multirow{2}{*}{$1 \begin{array}{l}\text { (Constant) } \\
\text { Disiplin Kerja }\end{array}$} & 1.341 & .525 & \multirow{2}{*}{\multicolumn{2}{|c|}{.304}} & 2.556 & .013 \\
\hline & .573 & .225 & & & 2.552 & .013 \\
\hline
\end{tabular}

a. Dependent Variable: Kepuasan Kerja

Berdasarkan tabel di atas, peneliti dapat membuat persamaan regresi sebagai berikut :

$$
\begin{gathered}
y=a+b_{1} x_{1}+b_{2} x_{2} \\
\text { kepuasan kerja } \\
=1.314+.573 \times \text { disiplin kerja }
\end{gathered}
$$

Dengan demikian, maka stres kerja memiliki pengaruh yang negatif, dimana peningkatan yang terjadi akan menguragi kepuasan kerja yang dimiliki oleh responden. Sementara, peningkatan disiplin kerja akan meningkatkan kepuasan kerja yang dimiliki oleh responden.

\section{PEMBAHASAN PENELITIAN}

Penelitian ini bertujuan untuk melihat pengaruh stres kerja dan disiplin kerja terhadap kepuasan kerja karyawan PT Angkasa Pura II Kantor Cabang Bandara Husein Sastranegara, Bandung. Untuk itu, peneliti telah mengambil data dalam bentuk kuesioner pada 66 orang karyawan dengan berbagai usia, jenis kelamin, pendidikan formal dan lama bekerja dari PT Angkasa Pura II Kantor Cabang Bandara Husein Sastranegara. Pada bagian sebelumnya, peneliti telah 
menyampaikan hasil penelitian yang dilakukan pada data-data yang sudah terkumpul.

Menurut Robbin dan Judge (2008:301), Kepuasan kerja adalah sikap umum seseorang individu terhadap pekerjaan nya. seseorang dengan tingkat kepuasan kerja yang tinggi akan menunjukkan sikap yang positif terhadap pekerjaan nya sedangkan seseorang yang tidak puas dengan pekerjaan nya akan menunjukkan sikap yang negatif terhadap pekerjaan. Menurut Luthans (2006:243), kepuasan kerja adalah hasil dari persepsi karyawan mengenai seberapa baik pekerjaan mereka memberikan hal yang dinilai penting. Dalam penelitian ini, indikator yang dipakai untuk kepuasan kerja adalah pekerjaan itu sendiri, pendapatan/gaji, kesempatan promosi, pengawasan/supervisi, dan rekan kerja. Dari hasil penelitian, peneliti menemukan bahwa responden sudah memiliki kepuasan kerja yang tinggi. Dengan demikian, mereka menikmati aktifitas kerja yang dilakukan.

Berdasarkan hasil penelitian deskriptif yang dilakukan, peneliti menemukan bahwa skor yang dimiliki oleh para responden, yaitu sebesar 2228 berada di rentang rendah menuju netral (cukup). Hal ini berarti bahwa para responden yang ada di lingkungan kerja, menghayati adanya ketidakpuasan terhadap kegiatan kerja yang dilakukan di lingkungan perusahaan.

Dalam penelitian ini, kepuasan kerja dapat dimunculkan oleh berbagai hal dalam lingkugnan kerja yang dimiliki. Salah satu faktor yang dapat mempengaruhi munculnya ketidakpausan kerja, adalah adanya stress kerja Menurut Luthans (2006:243), Stres kerja adalah keadaan emosi yang senang atau emosi positif yang berasal dari penilaian pekerjaan atau pengalaman kerja seseorang. Menurut Robbins (2003:577), stres merupakan kondisi dinamis yang ada di dalamnya seorang individu dikonfrontasikan dengan suatu peluang, kendala (constraints), atau tuntutan (demands) yang dikaitkan dengan apa yang sangat diinginkan nya dan yang hasilnya dipersepsikan sebagai tidak pasti dan penting.

Dari hasil penelitian, diketahui bahwa responden yang diteliti memiliki stres kerja yang berada di taraf tinggi, dengan demikian para responden merasa kegiatan kerja yang dilakukan dapat menimbulkan stres kerja yang dapat mengganggu pelaksaan kerja.

Hal ini sejalan dengan hasil penelitian yang ditampilkan oleh Nazenin dan Palupiningdyah (2014), yang mengungkapkan bahwa stres kerja berpengaruh negatif dan signifikan terhadap kepuasan kerja pada karyawan tetap bagian produksi. Hal ini berarti semakin tinggi stres kerja karyawan maka akan menurunkan kepuasan kerja karyawan, sebaliknya semakin rendah stres kerja karyawan maka akanmeningkatkan kepuasan kerja karyawan.

Selain Stress kerja, peneliti melakukan penelitian juga mengenai pengaruh antara Disiplin kerja dengan Kepuasan kerja. Menurut Atmodiwirio (2000:235), disiplin adalah suatu sikap, perbuatan untuk selalu mentaati tata tertib. Disiplin adalah sikap mental yang tercermin dalam perbuatan, tingkah laku 
perorangan, kelompok atau masyrakat berupa kepatuhan atau ketaatan terhadap peraturan peraturan, dan ketentuan yang ditetapkan pemerintah atau etik, norma, dan kaidah yang berlaku dalam masyarakat untuk tujuan tertentu.

Dari hasil penelitian, diketahui bahwa para responden yang diteliti memiliki displin kerja yang berada di taraf rendah, dengan demikian para responden merasa kegiatan kerja yang dilakukan memiliki standar kedisiplinan yang rendah. Hal ini sejalan dengan penelitian yang dilakukan oleh Mardiono dan Supriyatin (2014), yang mengungkapkan bahwa disiplin kerja berpengaruh signifikan terhadap kepuasan kerja karyawan PT Graha Megaria Sutos di Surabaya.

Selain mengukur pengaruh antara variabel dengan kepuasan kerja, peneliti juga mengukur pengaruh bersama (simultan) anara kedua variabel independen (stres kerja dan disiplin kerja) terhadap variabel dependen (kepuasan kerja). Peneliti menemukan bahwa terdapat pengaruh yang signifikan antara stres kerja dan disiplin kerja dengan kepuasan kerja karyawan PT Angkasa Pura II Kantor Cabang Bandara Husein Sastranegara. Dari hasil pengujian hipotesis, ditemukan bahwa Terdapat pengaruh yang signifikan antara stres kerja dan disiplin kerja terhadap kepuasan kerja pada para responden karyawan PT Angkasa Pura II Kantor Cabang Bandara Husein Sastranegara. Berdasarkan pengujian hipotesis tersebut, sebesar $16.7 \%$ dari kepuasan kerja dipengaruhi oleh stres kerja dan disiplin kerja yang dimiliki oleh responden

Dengan demikian, maka stres kerja memiliki pengaruh yang negatif, dimana peningkatan yang terjadi akan mengurangi kepuasan kerja yang dimiliki oleh responden. Sementara, peningkatan disiplin kerja akan meningkatkan kepuasan kerja yang dimiliki oleh responden.

\section{KESIMPULAN DAN SARAN}

\section{A. Kesimpulan}

Berdasarkan pengolahan data yang telah dilakukan, yang telah dipaparkan pada bagian sebelumnya, maka peneliti dapat membuat simpulan sebagai berikut

1. Para responden memiliki stres kerja yang berada di taraf tinggi, dengan demikian para responden merasa kegiatan kerja yang dilakukan dapat menimbulkan stres kerja yang dapat mengganggu pelaksaan kerja.

2. Para responden yang diteliti memiliki displin kerja yang berada di taraf rendah, dengan demikian para responden merasa kegiatan kerja yang dilakukan memiliki standar kedisiplinan yang rendah.

3. Para responden yang diteliti memiliki kepuasan kerja yang berada di taraf rendah. Dengan demikian para responden merasa kurang/tidak puas dengan aktifitas kerja yang dilakukan saat ini

4. Terdapat pengaruh yang signifikan secara simultan antara stres kerja dan disiplin kerja terhadap kepuasan kerja para responden karyawan PT 
Angkasa Pura II Kantor Cabang Husein Sastranegara, dimana sebesar $16.7 \%$ dari kepuasan kerja dipengaruhi oleh stres kerja dan disiplin kerja yang dimiliki oleh responden.

\section{B. Saran}

1. Peneliti menyarankan kepada para peneliti selanjutnya untuk dapat melakukan penelitian dengan jumlah sampel yang lebih banyak. Dengan demikian maka data yang dimiliki akan memiliki kecenderungan generalisasi yang lebih baik. Sehingga hasil penelitian yang dibuat oleh peneliti selanjutnya dapat menggambarkan kecenderungan dari variabelvariabel yang dibuat dengan lebih akurat.

2. Peneliti menyarankan kepada peneliti selanjutnya untuk dapat menggunakan teori-teori yang baru, dimana teori stres kerja dan kepuasan kerja akan mengalami perubahan dan perkembangan seiring waktu. Dengan demikian, para peneliti selanjutnya dapat menggunakan teori-teori dengan relevansi yang lebih baik.

3. Peneliti menyarankan kepada peneliti selanjutnya untuk dapat melakukan penelitian lebih lanjut mengenai faktor diluar variabel yang diteliti seperti kompetensi pada karyawan.

4. Peneliti menemukan bahwa terdapat pengaruh negatif yang signifikan antara stres kerja dengan kepuasan kerja. Dengan demikian, perusahaan akan dapat meningkatkan kepuasan kerja yang dimiliki oleh para karyawan di PT Angkasa Pura II Kantor Cabang Husein Sastranegara. Dengan meminimalisir berbagai situasi yang dapat memunculkan stres, maka perusahaan akan mampu meningkatkan kepuasan kerja yang dapat dimiliki oleh para responden.

5. Peneliti menemukan bahwa terdapat pengaruh positif yang signifikan antara disiplin kerja dan kepuasan kerja, dengan demikian pada saat responden menghayati bahwa lingkungan kerja memiliki lingkungan kerja memiliki tingkat kedisiplinan yang baik, maka akan memunculkan kepuasan kerja yang lebih tinggi pada para responden karyawan PT Angkasa Pura II Kantor Cabang Husein Sastranegara. Dengan demikian, dengan tetap menjaga kedisiplinan dalam aktifitas kerja, maka kepuasan kerja pada para karyawan akan dapat mengalami peningkatan.

\section{DAFTAR PUSTAKA}

Alibar, Muslim.2008. Faktor-Faktor yang Mempengaruhi Disiplin Kerja Pegawai pada Biro Kepegawaian Sekretariat Jenderal Departemen Hukum dan HAM RI, Tesis.Jakarta : Program Pascasarjana Universitas Indonesia.

Alves, M.G., Chor, D.,Faerstein,E.,Lopes,C.,\&Wer neck, G.L.2004. Short version of the "job street scale": a portugese-language adaption. Rev Saude Publica, Vol.38,No.2,1-7. 
Amran (2009). Pengaruh Disiplin Kerja Terhadap Kinerja Pegawai Kantor Departemen Sosial Kabupatern Gorontalo, 4(2),2397-2413.

AN, Ubaidilah. (2007). Mengantisipasi Stres Kerja. Retrieved November 17, 2011, from www.e-psikologi.com.

Andre, Rae.2008. Organizational Behaviour : an introduction to your life in organizations. New Jersey : Pearson Education.

Atmodiwirio, Soebagio.2000. Manajemen Pendidikan Indonesia. Jakarta : Ardadizya Jaya.

Aziri B., (2011). Job Satisfaction : A Literature Review. Faculty of Business and Economics. South East European University, Iiindenska 1200, Tetovo, Makedonia.

Daft, Richard L,2010, Era Baru Manajemen, Jakarta : Salemba Empat.

David Yong Gun Fiem Syed Shah Alam, Zaini Abdullah and Nilufar Ahsan (2009). A Study of Job Stress on Job Satisfaction among University Staff in Malaysia : Empirical Study. European Journal of Social Sciences - Volume 8, Number 1 (2009).

Davis, K., \& Newstrom, J.W. (2003). Human Behavioue at Work : Organizational Behavior. Singapore : Mc.Graw-Hill Book Company.

Ebuara, Victor Obule and Maurice Ayodale Coker.2012. "Influence of Staff Discipline and Attitude to Work On Job Satisfaction Lectures in Tertiary Institutions in Cross
River State". Public Policy and Administation Research Vol 2, No.3, 2012, pp:25-33, http://www.proquest.umi.com.

Evanita, Lenny.2013.Disiplin Kerja, Gaya Kepemimpinan, Pelatihan dan Kinerja Karyawan RSUD Lubuk

Sikaping.Tesis.Universitas Esa Unggul : Jakarta.

Faisal, Ahmad. 2014. Pengaruh motivasi dan disiplin kerja terhadap terhadap kepuasan kerja di PT. KAI (PERSERO) (Studi kasus pada PT. KAI Persero). Bandung : Universitas Widyatama.

Findik, Mehtap, Adem Ogut, dan Vural Cagliyan. 2013. "An Evaluation About PersonOrganization Fit, Job Satisfaction, And Turnover Intention : A Case of Health Institution". Mediterranean Journal of Social Sciences, Vol.4,No 11, 2013, pp:434-440.

Garry Dessler,2008. Human Resource Management. Edisi Sebelas, New Jersey : Pearson Education, Inc.

Gouzali Saydam.(2005). Manajemen Sumber Daya Manusia : Suatu Pendekatan Mikro. Jakarta : Djambaran.

Greenberg, Jerald dan Robert A. Baron. 2003. Behaviour in Organizations, Understanding and Managing The Human Side of Work. Third Edition. Allin and Bacon. A Division of Schuster. Massachuscets.

Handoko T. Hani,2000, Manajemen Personalia dan Sumberdaya Manusia, Edisi II, Cetakan Keempat Belas, Penerbit BPFE, Yogyakarta. 
Jehangir Muhammad., Nasir Kareem., Ayaz Muhammad Tahir., Shaheed Soherwardi, 2011. Effect Of Job Stress On Job Performance And Job Satisfaction. Interdisplicplinary Journal Of Contemporary Research In Business. Vol 13, No 7. Pg $567-589$.

Jogiyanto. (2007). Metodologi Penelitian Bisnis : Salah Kaprah dan Pengalamanpengalaman. Cetakan pertama. Yogyakarta : BPFE.

Karimi, R dan Alipour, F.2011. Reduce Job Stress in Organization : Role of Locus of Control. International Journal of Business and Social Science. Vol.2 No.18. Hal 231-236.

Kets de Vries, Manfred F. R.2001. Creating Authentizotic Organization : Well Functioning Individuals in Vibrant Companies. Human Relations, 54(1) : 101-111.

Koesmono,2006. Jurnal Manajemen Bisnis Volume 5 No 1. Fakultas Ekonomi Universitas Surabaya, Surabaya.

Luthans, Fred. 2011. Organizational Behaviour: An Evidence-Based Approach. New York : McGraw-Hill.

Mangkunegara, Anwar A.A Prabu, 2005, Manajemen Sumber Daya Manusia Perusahaan, Bandung : PT Remaja Rosdakarya.

Mangkunegara, Anwar A.A Prabu, 2007, Manajemen Sumber Daya Manusia Perusahaan, Bandung : PT Remaja Rosdakarya.

Mangkunegara, Anwar A.A Prabu, 2013, Manajemen Sumber
Daya Manusia Perusahaan, Bandung : PT Remaja Rosdakarya.

Moch Bahrodin.2007. Pengaruh Kepemimpinan, Motivasi dan Disiplin Kerja terhadap Prestasi Kerja Pegawai Pengadilan Negeri Purworejo, Tesis. Purwokerto : Program Pascasarjana Universitas Jenderal Soedirman.

Mondy, R. Wayne.2008. Manajemen Sumber Daya Manusia. Jakarta : Erlangga.

Moorhead, Gregory dan Ricky W. Griffin.2011. Perilaku Organisasi : Manajemen Sumber Daya Manusia dan Organisasi, Edisi 9. Salemba Empat.Jakarta.

Muhammad Mansoor, Sabtain Fida, Saima Nasir \& Zubair Ahmad.,2011. The Impact of Job Stress on Employee Job Satisfaction A Study on Telecommunication Sector of Pakistan, Journal of Business Studies Quarterly, Vol.2, No.3, pp. 50-56.

Mulyasa. 2002. Manajemen Berbasis Sekolah. Bandung : PT Remaja Rosdakarya.

Munandar, A.S, 2002, Manajemen Sumber Daya Manusia, Alphabet, Bandung.

Nurjaya, N. P. M. (2019). Pengaruh Sumber Daya Inti, Sumber Daya Kritikal, Market Based Terhadap Nilai Pelanggan Dan Kepuasan Pelanggan Serta Implikasinya Pada Loyalitas Pelanggan Pada Umkm Produk Gula Aren (Doctoral dissertation, Universitas Pasundan). 
Nurjaya, N., Erlangga, H., Hong, L. Z., \& Wijayanti, K. D. (2020). The Effect of Work Stress and Work Conflict on Employees Turnover Intention In Middle Small Micro Enterprises (MSMEs) In South Tangerang Region. International Journal of Educational Administration, Management, and Leadership, 51-62.

Pipin Latifah Indayani.2014. Pengaruh Iklim Organisasi Dan Motivasi Kerja Terhadap Kepuasan Kerja (Suatu Studi pada Dinas Sosial Kota Bandung).

Ratmaja, Candiasa et.al.2014. Kontribusi Stres Kerja, Pengelolaan Diri, dan Budaya Organisasi terhadap Produktivitas Kerja Pegawai di Lingkungan Dinas Pendidikan Pemuda dan Olahraga Provinsi Bali.e-Journal Program Pascasarjana Universitas Pendidikan Ganesha Program Studi Administrasi Pendidikan:Bali.

Riduwan \& Kuncoro.2011. Cara Menggunakan dan Memakai Path Analysis (Analisis Jalur). Bandung : Alfabeta.

Rivai, Veithzal dan Ella Jauvani Sagala,2013. Manajemen Sumber Daya Manusia untuk Peusahaan : Dari Teori ke Praktik. Edisi Kedua. Cetakan Kelima. PT. Rajagrafindo Persada. Jakarta.

Robbins, Stephen P. dan Timothy A. Judge. 2008. Perilaku Organisasi Edisi ke-12. Jakarta : Salemba Empat.
Siagian, Sondang.,2008. Manajemen Sumber Daya Manusia. Jakarta.

Soedjono,2000, Strategi Sumber Daya Manusia, Vol. 4, No.4, hal 233-256.

Sugiyno.(2009). Metode Penelitian Bisnis (Pendekatan Kuantitatif, Kualitatif, dan R\&D). Bandung : Alfabeta.

Sugiyono, (2003). Metode Penelitian Bisnis. Edisi 1, Bandung : Alfabeta.

Suliyanto.2003. Metode Riset Bisnis. Bandung : Alfabeta.

Surjana, Ficky.2015. Dampak Stres Kerja dan Disiplin Kerja terhadap Kepuasan Kerja Karyawan (Studi pada Karyawan PD Sapta Jaya Bandung), Tesis. Bandung : Program Pascasarjana Universitas Kristen Maranatha. Veithzal Rivai dan Deddy Mulyadi. 2009. Kepemimpinan dan Perilaku Organisasi.Jakarta : PT Rajagrafindo Persada.

Vigoda,E., dan Golimbiewski, R.T. (2001). "Citizenship Behavior and the Spirit of New Managerialism. A Theoritical Framework and Challenge for Governance".American Review of Public Administration. Vol. 31 No. 3.September 2001273 295.

Wijono,Sutarto.(2005). Pengaruh Kepribadian Tipe A, Locus Of Control Eksternal, Peran dan Iklim Organisasi terhadap Stres dan Prestasi Kerja, Disertasi. Jakarta : Program Pascasarjana Universitas Indonesia. 